\title{
THE MICHIGAN ENABLING ACT FOR NON-PROFIT MEDICAL CARE PLANS*
}

\author{
WILLIAM J. BURNS $\dagger$
}

"Michigan's Doctors Offer Low Cost Family Service," shouted newspaper headlines throughout the Wolverine State last September 19. "A group medical care plan for families with limited incomes was adopted yesterday by the Michigan State Medical Society," the news story stated. "It will make available to participating groups a wide range of medical services at nominal cost."

While the press with generous columns heralded this action as an answer to the medical economic problem, some gentlemen of the fourth estate suggested the medical profession was taking a very revolutionary plunge. Few stories presented the background of nine years of study and research by the Michigan State Medical Society preceding its final decision to adopt a plan for assisting those in the lower income groups to obtain needed medical service. And only one or two reporters mentioned the Michigan Enabling Act ${ }^{1}$ upon which the whole new structure rests!

\section{Enabuing Act for Group Medical Care}

In I93I, the Michigan State Medical Society began its pioneer study of the distribution of medical services in Michigan. After almost a decade of research costing approximately $\$ 30,000$, which emphasized the vital need for a firm legal foundation for any medical service plan, the Society gave authority to its Committee on Legislation to develop a group medical care bill for introduction in the state legislature. This significant proposal was carefully drafted and re-drafted, revised and corrected, and finally presented to the Michigan legislature on February 20, 1939. It was approved by the House of Representatives four weeks later, passed by the Senate on May 4th, and signed by the Governor on May 17 th. Given immediate effect, this Michigan law represented the first group medical care enabling act on the statute books of a large industrial state. As will be seen, its passage was not uneventful.

- This article will consider only the Enabling Act and its legislative history and not the plan recently adopted under the authority conferred by the Act. For a description of a state medical care plan established under professional auspices, see Peart and Hassard, The Organization of California Physicians' Service, injra, p. 565 . ED.

TLL.B., 1925, St. John's University. Executive Secretary, Michigan State Medical Society. Formerly Executive Secretary, Toledo Academy of Medicine, and Wayne County Medical Society, Detroit.

${ }^{2}$ Mich. Acts 1939, act No. 108. 


\section{RÉsumé of the Original Bill}

The measure as introduced represented the joint thinking of a voluntary group and a branch of the state government, the Michigan State Medical Society and the Michigan Department of Insurance, to which the physicians applied for help with technical questions. A digest of House Bill No. 215 follows, the sections drafted by the Department of Insurance being indicated by an asterisk:

Section $x$. Intent of act: "to promote a wider distribution of medical care, and to maintain the standing and promote the progress of the science and art of medicine in this state."

Section 2. General purposes: Act permits formation of a corporation to establish, maintain, and operate a voluntary non-profit medical care plan whereby subscribers, by paying a small monthly fee, are entitled to medical and surgical care, appliances and supplies, in their homes, in hospitals, and in physicians' offices. Such other benefits may be added from time to time as the corporation may determine. The plan is subject to supervision by Commissioner of Insurance in order to protect the interests of subscribers.

Section 3.* Manner of subscribing to articles of incorporation.

Section 4.* Fees which must be paid upon incorporation.

Section 5.* Plan to be submitted to Commissioner of Insurance for approval.

Section 6.* Commissioner of Insurance may inspect records of corporation.

Section 7.* Annual report shall be filed with the Insurance Commissioner.

Section 8. Board of Directors shall have representation from medical profession and the public.

Section 9. Corporation has authority to provide all medical benefits, but may divide benefits into classes or kinds, and limit same in quantity, and to certain areas. ${ }^{2}$

Section 1o. Each doctor has the right to register with the corporation to provide medical service. The physician-patient relationship shall be maintained. No restrictions shall be imposed on a doctor of medicine as to methods of diagnosis or treatment.

Section II.* Provision for reasonable reserves. Funds shall be invested only in securities permitted life insurance companies.

Section 12. Medical care shall be in accordance with accepted medical practice in the community.

Section 13. Payments in whole or in part may be made in behalf of indigent and borderline subscribers by private corporations, associations, groups, individuals and in behalf of indigents by governmental agencies; but cach contract shall be with the subscriber (the patient), so that no third party comes between patient and physician.

Section 14. No action at law based upon or arising out of the physician-patient relationship shall be maintained against a non-profit medical care corporation.

Section 15 . The corporation is not an insurance company but "is hereby declared to be a charitable and benevolent institution," free from taxation. ${ }^{3}$

Section 16. Violation of provisions of act constitutes a misdemeanor.

Section 17 . Severability clause.

\section{Changes Made by the Legislature}

The bill's progress through Michigan's two legislative houses was stormy. At no time was any question raised concerning the merits of the proposal, but the issue was beclouded by the aggressive lobby of a group of healers (not doctors of medicine)

2 The purpose of authorizing classification of benefits as to kind, quantity, and area was to permit experimentation in the formative stage.

Tax exemption will result in greater benefits to the subscribers. 
who desired to be included in this purely medical program. To have acceded to their desires would have lost the support of Michigan's 6,I43 doctors of medicine who were interested in and working for this social experiment. However, after several major engagements, the Legislature passed the bill without any damaging amendments.

To help differentiate group medical care programs from insurance contracts, the insurance lobby suggested the inclusion of two clauses in Sections 2 and 3, a request which was readily granted. The addition to Section 2 reads as follows: "No contract by or on behalf of any non-profit medical care corporation shall provide for the payment of any cash or other material benefit by that corporation to the subscriber or his estate on account of death, illness or injury, nor be in any way related to the payment of any such benefit by any other agency." The following provision was added to Section 3: "The persons so associating shall subscribe to articles of association which shall contain the name by which the corporation shall be known, such name not to include the words insurance, casualty, surety, health and accident, mutual or other words descriptive of the insurance or surety business, and such name shall not be sufficiently similar to that of any insurance or surety company doing business in this or other states at the time of incorporation, to tend to create confusion in identity therewith, in the judgment of the commissioner of insurance."

A supporting clause was recommended by the Insurance Department for Section 2 to the effect "that the provisions of the Michigan Non-Profit Corporation Law" shall be applicable to all corporations formed under or governed by this act, except as herein otherwise specifically provided."

Finally, the legislature strengthened the provision permitting free choice of doctor, by adding the following penalty clause to Section ro: "Any employee, agent, officer or member of the board of directors of any such corporation who shall influence or attempt to influence any person in the choosing and selecting of his own physician, shall be guilty of a misdemeanor, and upon conviction thereof shall be punished as provided by the laws of this state."

\section{Legal Questions Considered in Connection with the Act}

A new era in medical legislation began with the passage of the Michigan Act authorizing and regulating the incorporation of non-profit medical care plans. Formerly it was generally held that medical service plans need not be organized under existing insurance laws and that special enabling legislation was not necessary. Following the lead of Michigan, state after state has focused attention on the legality of medical service plans being operated without the benefit of legislation or without qualifying under the insurance laws.

The primary legal problem involves the question of whether a medical service plan should be subjected to special regulation as insurance or whether such a plan should be considered merely as a service agreement. The essential consideration is the importance of the undertaking from the point of view of the public and the

‘ Mich. Acts 1931, act No. 327, $\$ \$ 117-132$. 
likelihood that the organization promising to make provision for medical services will be able to perform the agreement. The first step toward regulation was to insist that medical service plans should qualify under the insurance laws which are specifically designed to protect persons who purchase contracts offering future benefits. Without a special enabling act, the distinction between a medical service contract and an insurance contract is difficult to draw. In addition, there were two obstacles to the organization of medical service plans under insurance regulations: the requirement of large capital funds, and taxation. The purpose of the Enabling Act is to create special regulations governing the operation of medical service plans, to place them under the supervision of the Commissioner of Insurance-but to remove the obstacles to regulation under the insurance laws. The Michigan Enabling Act accomplished this purpose and definitely established the special status of medical service plans.

A second important legal problem deals with the question of the corporate practice of medicine. Courts have generally held that the corporate practice of a profession is undesirable and illegal. Consequently, the undertaking by a corporation to arrange for the obtaining of professional services calls for careful analysis of the effect on established legal principles and related laws, such as the medical practice act. In the Michigan Enabling Act, considerable study was given to the phrasing of Section 2 in order to indicate clearly that the corporation itself was not authorized to engage in the practice of medicine but merely to be a fiscal agent for the subscriber and for the physicians: "... medical care is provided at the expense of such corporation to such person or groups of persons of low income as shall become subscribers to such plan." The Act does not state that medical care is to be provided by the corporation, but only "at the expense of such corporation." Medical care will continue to be provided by licensed and registered doctors of medicine in the same manner as private medical practice is now carried on.

A third essential legal problem involves the responsibility of physicians under the medical service plan. One aspect of this responsibility deals with liability for malpractice. Again, the existing legal attitude places responsibility for malpractice on the individual physician. Whether this responsibility can or should be assumed by corporations requires the full consideration of many far-reaching consequences. In Section I4 $_{4}$ of the Michigan Act, the liability for alleged malpractice remains with the individual physician, where it properly belongs.

Another aspect of the responsibility of physicians pertains to their liability for fulfilment of services offered as benefits under the medical service contract. The basic liability for the services offered would seemingly repose with the corporation issuing the medical service contracts. However, most medical service corporations depend on an agreement with participating physicians for the provision of the services offered as benefits. Although the Michigan Act specifically provides in Section 12 that "all medical care rendered on behalf of a non-profit medical care corporation shall be in accordance with the accepted medical practice in the community at all times," and states in Section to that "a non-profit medical care corporation shall 
impose no restrictions on the doctors of medicine who treat its subscribers as to methods of diagnosis or treatment," nevertheless, despite the usual ethical controls, some legal problems may perhaps arise concerning the responsibility of physicians to the corporation and to the subscriber entitled to benefits under a medical service contract.

\section{A Sociar Responsibility Feelingly Met}

Michigan's Act No. 108 of 1939 is the result of nine years' labor and education by the Michigan State Medical Society. It represents an evolutionary step forward. Michigan's doctors hope it will aid them in their difficult task of distributing quality medical care to all. The public has placed its faith in the medical profession; and the attitude of the press is best epitomized by the following sentence from one of the many eulogistic editorials on the group medical care plan of the Michigan State Medical Society:

"As for the new medical plan the trial of it will be the true test; but, at very least, it evidences a growing disposition toward social responsibility. When a responsibility is cordially and feelingly met, it is better met than when compelled by law."

\section{Editor's Note: Enabling Acts for Medical Care Corporations in Other States}

During the I939 legislative sessions bills authorizing the establishment of non-profit medical care corporations were introduced in at least eleven states in addition to Michigan and were enacted in Connecticut, Pennsylvania, and Vermont. In New York State enabling legislation was enacted for non-profit "medical expense indemnity" corporations. In this note, a brief indication of the principal provisions of the enacted laws will be given, together with citations to the unsuccessful measures.

Connecticut: This act, $\dot{H}$. B. No. 857 , approved June 20, 1939, permits the creation of a non-profit medical service corporation by not less than seven residents of the state and also authorizes the state medical society and eight named county societies to "jointly or severally incorporate for the purpose of operating a medical service corporation." The medical services are to be provided by registered doctors of medicine; hospital services are excluded. The consent of the insurance commissioner to incorporation is required and is conditioned on his finding that the charter is in accordance with the act and "in the public interest." Not less than \$5,000 must be deposited to secure performance of obligations. The contract must contain seven prescribed provisions. Group contracts (except to families) are forbidden. Apparently the contract may provide for the payment of an indemnity as well as for furnishing services (see $\$_{4}, \mathrm{cl}$. B.). The commissioner may disapprove rates found "excessive, inadequate, or discriminatory." Either party to disputes between a subscriber and the corporation may refer the dispute to the commissioner, whose decision is subject to judicial review. The property of the corporation is exempt from taxation.

Pennsylvania: In this state two laws, sponsored by the medical profession, were passed. The first, H. 685, amends the non-profit corporation law to provide for the creation of non-profit medical service corporations. The second act, H. 686, provides in considerable detail for the regulation of corporations created under H. 685. Supervision over these corporations is vested in the Department of Health and in the Insurance Department. They are authorized to provide medical services (as defined in the law) to persons of "low income," i.e., persons without dependents having an average weekly income for the preceding 25 weeks of $\$ 30$ or less; with one dependent, of $\$ 45$ or less; and with more 
than one dependent, of $\$ 60$ or less. Doctors of medicine are to have majority control and the services provided must be obtained only from such doctors and be under medical direction and control. Free choice of physician is provided for. The corporation may define the services which it will render and require a physical examination of applicants. Applicants found in need of immediate care may be required to pay a fee therefor. No cash benefits may be paid. Authority is given to state and local officials charged with providing medical care to needy persons to provide medical services by subscribing at public expense to the corporation's service. Corporations are tax exempt. Both bills were approved June I7, 1939.

Vermont: This act, S. B. No. 60, approved April 14, 1939, authorizes three or more persons licensed to practice medicine to incorporate under the general corporation laws a non-profit medical service corporation to establish and operate a plan to provide medical or medical and dental services by licensed practitioners to subscribers. The corporation must obtain a permit to operate from the Commissioner of Banking and Insurance. The Commissioner may refuse the permit if he finds the rates "excessive, inadequate or unfairly discriminatory." The act prescribes certain provisions which must appear in the contract. These are derived chiefly from insurance law sources, but one such provision is a statement that the subscriber may choose any licensed physician who agrees to be governed by the corporation's by-laws concerning payment of fees. Corporations created under the act are exempt from taxation. At the end of the act is a section which confers the same privileges of incorporation on three or more persons licensed to practice dentistry, osteopathy, chiropractic, or chiropody.

Netv York: This act, N. Y. Laws r939, c. 882, to be codified as N. Y. Consor. L. c. 28, art. IX-c, effective June 15, 1939, forms part of a comprehensive revision of the New York Insurance Law and combines in the same article provisions both for hospital service and for medical expense indemnity corporations. "Medical expense indemnity" is defined to consist "of reimbursement for medical care provided through duly licensed physicians, for nursing service and of furnishing necessary appliances, drugs, medicines and supplies." Discrimination in plans against legally recognized "schools of medical practice" is forbidden. The corporations may be organized under either the membership, or the cooperative, corporation law and their conversion into corporations organized for profit is prohibited. They are subject to specified provisions of general applicability in the Insurance Law. They must obtain from the superintendent of insurance permits to solicit subscribers and, after subscribers have been enrolled and have made at least one-sixth payments, licenses to do business. Licenses may be refused if, after investigation, the superintendent finds issuance to be "contrary to the interest of the people." Contracts must be for a I2-month period and contain certain specified provisions. Group contracts may be written for families, employers, and employee associations, the groups being defined by the statute. Solicitation expenses may not exceed $20 \%$ of payments received the first year, $15 \%$ the second, and $10 \%$ thereafter. Other non-benefit expenses may not exceed $20 \%$. After the first year each corporation must begin the accumulation of a "special contingent surplus" at the rate of $2 \%$ of net premium income per year for four years and $2 \frac{1}{2} \%$ thereafter until the surplus reaches $\$ 100,000$. A medical expense indemnity and a hospital service corporation may together issue "a combined contract" but neither can do so separately. Each may act as the agent of the other without license. Both types of corporations are tax exempt.

Bills Failing of Passage: Arkansas, S. 304; California, S. 548, A. 2494, A. 250r; Illinois, H. 977; Missouri, H. 620; Ohio, S. 104; Utah, S. 176, S. 177; Washington, S. 311, H. 199; Wisconsin, A. 40r. Of these bills, all but the Illinois and Ohio bills provided for both medical and hospital services to be provided by the corporations authorized. 